\title{
Ecological Aspects of a Wood Turtle, Glyptemys insculpta, Population at the Northern Limit of its Range in Québec
}

\author{
Andrew D. WAlde ${ }^{1,2,3}$, J. Roger Bider ${ }^{1}$, Claude Daigle ${ }^{4}$, Denis Masse ${ }^{5}$, \\ JeAn-Claude Bourgeois ${ }^{6}$, JACQues Jutras ${ }^{7}$, and Rodger D. Titman ${ }^{2}$
}

${ }^{1}$ St. Lawrence Valley Natural History Society, 21125 chemin Ste.-Marie, Ste.-Anne-de-Bellevue, Québec, H9X 3 Y7 Canada

${ }^{2}$ Department of Natural Resources, Macdonald Campus of McGill University, 21111 Lakeshore Road, Ste.-Anne-de-Bellevue, Québec H9X 3V9 Canada

${ }^{3}$ Corresponding author: P. O. Box 36, Helendale, California 92342 Email: awalde@ hotmail.com

${ }^{4}$ Société de la faune et des parcs du Québec, Direction de la recherche sur la faune, 675, boulevard René-Lévesque Est, Québec, Québec G1R 5V7 Canada

${ }^{5}$ Parcs Canada, Parc national de la Mauricie, 2141, chemin Saint-Paul, Saint-Mathieu-du-Parc, Québec G0X 1N0 Canada

${ }^{6}$ Société de la faune et des parcs du Québec, Direction de l'aménagement de la faune de la Mauricie, 5575, rue Saint-Joseph, Trois-Rivières, Québec G8Z 4L7 Canada

${ }^{7}$ Société de la faune et des parcs du Québec, Direction du développement de la faune, 675, boulevard René-Lévesque Est, Québec, Québec G1R 5V7 Canada

Walde, Andrew D., J. Roger Bider, Claude Daigle, Denis Masse, Jean-Claude Bourgeois, Jacques Jutras, and Rodger D. Titman. 2003. Ecological aspects of a Wood Turtle, Glyptemys insculpta, population at the northern limit of its range in Québec. Canadian Field-Naturalist 117(3): 377-388.

As part of a conservation research initiative, a population of Wood Turtles (Glyptemys insculpta) at the northern limit of its range was studied to ascertain characteristics of its demographics, morphometrics, density, mortality, feeding, and mating activities. Turtles were captured and marked during the activity period in 1996 and 1997. In addition, 20 individuals were radio-tracked weekly. A total of 188 turtles was captured and the size of the population in the study area was estimated at 238 turtles. The estimated population density based on this calculation is 0.44 turtles/ha. This is less than other studies indicating that population densities are greater in southern populations. Turtles from this population were large (carapace length of males $=214.5 \pm 4.21$ $\mathrm{mm}$, females $=201.1 \pm 10.88 \mathrm{~mm}$ ) which supports the hypothesis that turtle size is negatively correlated with number of frost free days. The sex ratio was not significantly different from 1:1. Juvenile turtles accounted for $31.4 \%$ of the population. Observations of feeding habits support the claim that Wood Turtles are opportunistic omnivores. Of the 35 mating or courtship events observed, $77 \%$ occurred in the fall and half of them between 11:00 and 13:00. Although limb and tail injuries and parasites were observed on many turtles, no dead turtles were observed. This last result, combined with the high rate of recruitment and even sex ratio suggests that this population is stable, making it an ideal population with which to make comparisons with other studies in areas where the species could be in decline.

Key Words: Wood Turtle, Glyptemys insculpta, Emydidae, morphology, density, ecology, Québec.

The Wood Turtle, Glyptemys insculpta, ranges throughout the northeastern United States and southeastern Canada, from central Ontario, east to Nova Scotia, and south to Virginia (Ernst et al. 1994). Wood Turtle populations are scattered and disjunct throughout their distribution (Ernst 2001a; Niederberger and Seidel 1999) and it is thought that there is little chance now of interpopulation exchange or natural recolonization into areas from which they have been extirpated (Harding and Bloomer 1979; R. Brooks personal communication). In southern Québec, Wood Turtles are considered to be widespread, but uncommon, up to $47^{\circ}$ north latitude (Beaulieu 1992; Bider and Matte 1996; Daigle 1997).

In 1992, Glyptemys insculpta (as Clemmys insculpta) was listed in Appendix II of the Convention on the International Trade of Endangered Species of Flora and Fauna (CITES) (Buhlmann 1992, 1993). Currently, the Wood Turtle is listed as threatened, endangered, or protected by law in most of the U.S. states within its range (Harding 1991*; Klemens 1992*; Buhlmann 1993; Levell 2000). In Canada, this species has been assigned the status of "vulnerable" by the Committee on the Status of Endangered Wildlife in Canada (COSEWIC) (Green 1996; Litzgus and Brooks 1996*). In Québec, the Wood Turtle was included on a list of species susceptible to being declared vulnerable or threatened (Beaulieu 1992). A recent status report on the Wood Turtle in Québec recommended a status of vulnerable (Galois and Bonin 1999), although no legal status has been assigned.

Recent studies have indicated that many Wood Turtle populations have undergone significant declines (Harding and Bloomer 1979; Garber 1989; Harding 1990; Ernst et al. 1994; Gilhen et al. 1994*; Garber and Burger 1995; Niederberger and Seidel 1999; Ron 
Brooks personal communication). Some of these authors have suggested that collection for the pet trade is the single greatest cause for "population crashes", and have made conservation recommendations e.g. Litzgus and Brooks 1996*) which advocate not revealing any exact location. Many of these authors admit that habitat loss and fragmentation contribute significantly to declines as well. Ernst (2001a) states that habitat destruction and alteration are the most serious problems facing Wood Turtles. Levell (2000), in a review of the pet trade, argues that this may not be as widespread a problem as has been sometimes indicated for the Wood Turtle. He suggests that increased human population pressures such as road mortality and habitat fragmentation, degradation and destruction are the most serious threats. Although it is difficult to assess habitat decay and the subsequent decline of a species without long-term studies, one study in Québec documented the effect of present agricultural practices. These were shown to be causing decreased recruitment into the population and an increased rate of injuries, mutilations and even death in adults (Saumure and Bider 1998). Another study, in Connecticut, concluded that human recreational activities caused the extirpation of two populations (Garber and Burger 1995).

There have been numerous studies on Wood Turtles which have examined habitat requirements, home range, daily activities, reproduction, dominance and habitat use (Powell 1967; Carroll and Ehrenfeld 1978; Ernst 1986; Lovich et al. 1990; Brewster and Brewster 1991; Ross et al. 1991; Quinn and Tate 1991; Brooks et al. 1992; Kaufmann 1992, 1995). The most complete studies of ecology and life histories are those of Harding and Bloomer (1979) in Michigan and New Jersey, and Farrell and Graham (1991) in New Jersey. More detailed studies of Wood Turtle life histories must be conducted (Harding and Bloomer 1979; Farrell and Graham 1991; Ross et al. 1991; Brooks et al. 1992; Litzgus and Brooks 1996*; Saumure 1997*; Ernst 2001b). That this data-base is still inadequate is demonstrated by a management recommendation from the COSEWIC report that further studies of Canadian Wood Turtle populations need to be started or expanded (Litzgus and Brooks 1996*).

The objectives of this study were to gather base line data on morphometrics, density, feeding, mating, predation, and parasites from a population at the northern limit of the Wood Turtle's range in Québec. Results were then compared with published data from more southerly populations. Information concerning characteristics from a northern population are important in the planning and application of conservation and management strategies for this species.

\section{Materials and Methods}

Turtles were located and marked from May to October of 1996 and 1997 along a $7.05 \mathrm{~km}$ section of a meandering river and the surrounding habitats in
Municipalité Régionale de Comté (MRC) Le Centre de la Mauricie, Québec, Canada $\left(46^{\circ} \mathrm{N}, 73^{\circ} \mathrm{W}\right)$. Some of the tributary creeks and gravel roads in the general area were also surveyed. The total area over which turtles were captured was 538 ha. During May of 1996 and 1997, an intense search of the study area was undertaken to locate and mark Wood Turtles. This was accomplished by canoeing and walking along the river and hand capturing or dip-netting the turtles.

The geology of the area is that of an esker (Allard $\left.1978^{*}\right)$; gravel and sand with exposed granitic outcrops. The river is between 5 and $10 \mathrm{~m}$ wide and 0.1 $2 \mathrm{~m}$ deep, depending on the season and precipitation patterns. The river bottom is sandy with gravel deposits. The flood plain is predominantly Speckled Alder (Alnus rugosa) thicket, with several ox-bow lakes and Beaver (Castor canadensis) ponds. Vegetation beyond the flood plain is at the border of the boreal/Great Lakes St. Lawrence Lowland forest (Farrar 1995) with White Spruce (Picea glauca), White Birch (Betula papyrifera), and Trembling Aspen (Populus tremuloides) dominating with some maple species (Acer spp.) also present. The number of frost free days (FFD) in this area was 100 (Wilson 1971). Most of the land in the study area was privately owned and had little to no development on it, although logging and aggregate mining have historically been and continue to be economic factors. The number of summer homes in the area was increasing.

For each turtle captured, date, time, location, behaviour (e.g. basking, feeding), weather, and temperature were recorded. The maximum straight line carapace (CL) and plastron lengths (PL) were measured using vernier calipers (forester type, $\pm 1 \mathrm{~mm}$, Haglof, Sweden) and the turtle was weighed using spring scales (Pesola, $\pm 50 \mathrm{~g}$ or $\pm 10 \mathrm{~g}$, Switzerland). Adult turtles were sexed using characteristics of length of carapace and the presence or absence of male secondary sexual characteristics, males exhibiting plastron concavity and a longer, thicker, preanal tail (Wright 1918; Harding and Bloomer 1979). Female turtles were palpated for the presence of eggs. Turtles below a minimum size were considered to be immature (minimum size was determined from results).

Age was determined by counting growth annuli, starting from the flat hatchling section and proceeding outward. This method is considered a reliable estimator of age until approximately 15-20 years of age for Wood Turtles, after which it is thought to be less reliable as the smaller annuli are too difficult to count, especially in the field (Harding and Bloomer 1979; Harding 1985*; Lovich et al. 1990). At our northern location, the growing season is short and not interrupted by aestivation; therefore, only one annulus would be expected per year. The minimum age of a Wood Turtle was assessed by counting all discernable annuli. Limb and tail injuries were recorded, as well as presence/absence of parasites and shell abnormal- 
ities. Posterior carapace marginal scutes were marked for later individual identification (Cagle 1939), using a $6 \mathrm{~mm}$ rat-tail file that made permanent U-shaped notches, with a numbering system adapted by Saumure (1995*) from one described by Froese and Burghardt (1975).

Radio transmitters (Holohil AI-2m(4) with batteries lasting two years) were installed in May of 1996. As many as 20 turtles were monitored weekly in both years of the study until hibernation had begun. In 1997, turtles were located daily from 26 May until the end of June to aid in locating nesting sites. Radio transmitters were encased in a piece of brass pipe with a $30 \mathrm{~cm}$ whip antenna. A transmitter was attached to each turtle by drilling two holes in the marginal scutes and bolting it on. Transmitters were attached well off center near the posterior on males and centered at the front on females.

Results from telemetry and visual surveys indicated that these turtles rarely went outside the study area. Immigration and emigration were considered to be almost non-existent; therefore, population estimates were calculated using the Lincoln-Peterson method (Lindeman 1990; Pollock et al. 1990).

Differences between sexual and morphological parameters were tested for using the Student's $t$-test and chi-square $\left(\chi^{2}\right)$. Correlations among populations were analyzed using SigmaPlot 8.02 statistical software (SPSS Inc. 2002). Statistical significance was accepted at $\mathrm{P}<0.05$.

\section{Results}

\section{Population Structure}

A total of 188 Wood Turtles (55 males, 83 females, and 50 immatures) was captured and marked during 1996 and 1997. The size of the population was estimated at 238 turtles (95\% confidence limits 191-285) using the Lincoln-Peterson index. The estimated density based on this calculation is 0.44 turtles/ha.
The sex ratio of all turtles captured was $1: 1.51$, males to females (55 males: 83 females) which is significantly different from one to one $\left(\chi^{2}=5.7, \mathrm{P}<0.05\right)$. This, however, represents a biased sample as 29 females were first captured at nesting areas. The removal of these females gives a $1.0: 0.98$, male to female adult sex ratio (55 males : 54 females) which is not significantly different from $1: 1(\mathrm{P}>0.05)$.

Fifty immature turtles $(31.4 \%$ of 159$)$ were captured during the study (Figures 1,2). The results of spring surveys in May (1996 and 1997) revealed a ratio of adult to immature captures of approximately $4: 1$. A less intense survey in the fall of 1997 revealed a $2: 1$, adult to immature capture ratio, which is significantly different from the spring ratio $\left(\chi^{2}=4.34, \mathrm{p}<0.05\right)$.

Immature turtles were categorized by being smaller than the smallest recorded male or female, with adults exhibiting secondary sexual characteristics (males) or being gravid (females). The smallest male as determined by secondary sexual characteristics had a CL of $170 \mathrm{~mm}$ (Figure 1) and also had the fewest annuli of any distinguishable male, 11 (Figure 2). The smallest gravid female had a CL of $181 \mathrm{~mm}$ and 20 annuli. The youngest female known to be gravid had a CL of $203 \mathrm{~mm}$ and 14 annuli.

The smallest male observed courting or mating had a CL of $205 \mathrm{~mm}$ and 15 annuli; the smallest female observed in these activities had a CL of $188 \mathrm{~mm}$ and 14 annuli. It is not known whether this turtle became gravid.

Males were significantly larger than females for measurements of mean CL and weight but not for PL (Table 1). The mean numbers of annuli for males and females were not significantly different $(\mathrm{P}>0.05)$ (Table 1). One female turtle had 33 countable annuli. Age frequency distribution is represented in Figure 2.

\section{Dietary Habits}

Feeding was observed several times during the active months, except October. Turtles were seen eat-

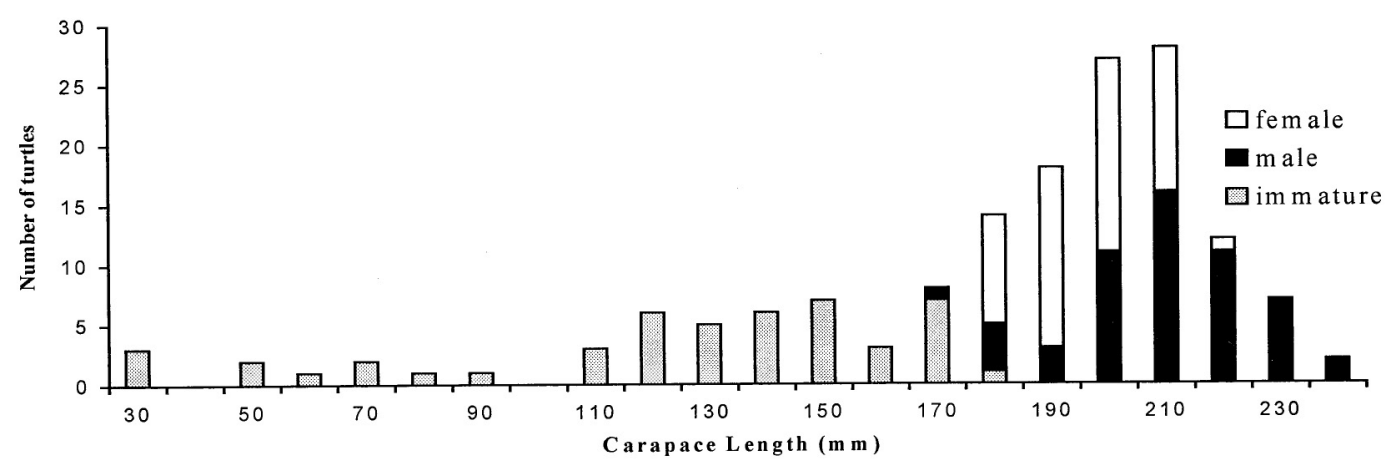

FIGURE 1. Population size structure (carapace length in $\mathrm{mm}$ ) of 156 Wood Turtles captured from Municipalité Régionale de Comté Le centre de la Mauricie, Québec, Canada in 1996 and 1997. Turtles captured by biased sampling techniques (i.e. at nesting areas) have not been included. 


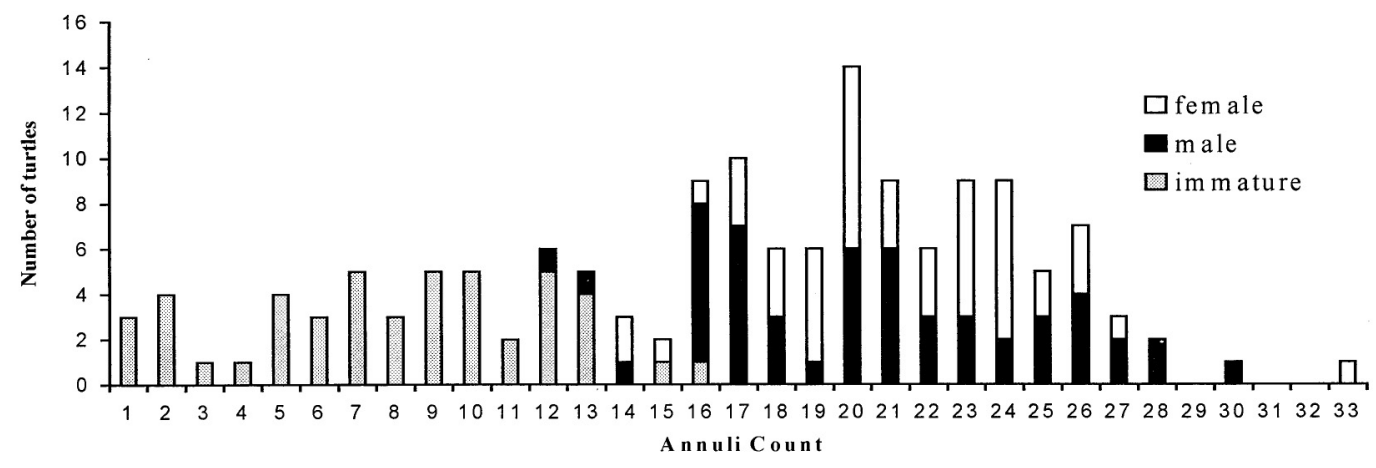

Figure 2. Population age structure (annuli count) of 153 Wood Turtles captured from Municipalité Régionale de Comté Le centre de la Mauricie, Québec, Canada in 1996 and 1997. Turtles captured by biased sampling techniques (i.e. at nesting areas) have not been included.

ing several species of plants; leaves and fruits of strawberry plants (Fragaria sp.) and birch leaves (Betula papyrifera) being commonly eaten. One turtle was observed snipping fern stems at the base and then eating the tip of the frond. Two genera of mushrooms, Boletus and Amanita, were consumed on several occasions. Invertebrates eaten included slugs, worms and millipedes. Also, turtles were seen fighting over and eating items of carrion, including mice, toads (Bufo americanus), and fish. On five occasions, fighting (involving pushing, biting, and hissing) was observed over a piece of carrion; in one instance four turtles were involved. On three separate occasions, turtles were observed with feathers in their mouths.

\section{Mating}

Courting and mating activities were observed from May until November. Over the two year study, 35 courting or mating events were observed; 27 (77\%) occurred in the fall, $17(49 \%)$ of which occurred in October alone. Mating activities appeared to be more frequent during midday with more than 18 (51.4\%) occurring between 11:00 and 13:00. Some females and males engaged in mating activities more than once in a season and with more than one partner. One male was observed coupled with five different females. Turtles were also recorded in mating activities with the same partner during both years of the study.

\section{Injuries, predation, and parasites}

Sixty-five (34.6\%) turtles had scars from injuries. Of the 188 turtles caught, 46 (28 females, 12 males, and 6 immature) had a part of their tail missing. The proportion of males and females with tail injuries did not differ $\left(\chi^{2}=2.55, \mathrm{P}>0.05\right)$, but proportionately more adults were injured than immature turtles $\left(\chi^{2}=7.71\right.$, $\mathrm{P}<0.01)$. Eighteen $(9.6 \%)$ turtles had at least partial loss of one limb, with or without a tail injury and 6 (3.2\%) had partial loss of two limbs. Differences between sexes $\left(\chi^{2}=0.05, \mathrm{P}>0.05\right)$ or between adult and immature turtles $\left(\chi^{2}=3.70, \mathrm{P}>0.05\right)$ for leg damage were not significant. No dead turtles were found during the study. Animals seen in the study area which could have caused these mutilations included Red Fox (Vulpes fulva), Muskrat (Ondatra zibethica), Otter (Lontra canadensis), Striped Skunk (Mephitis mephitis), Raccoon (Procyon lotor), feral and domestic cats (Felis domestica), dogs (Canis familiaris) and other Wood Turtles.

Leeches (Placobdella sp.) were found attached to many parts of turtles but were most common on the skin of the limb sockets. Leeches were seen on turtles in May (70\% of observations), June, September, and October.

TABLE 1. Wood Turtle morphometrics from a population in Municipalité Régionale de Comté Le Centre de la Mauricie, Québec, 1996 - 1997.

\begin{tabular}{|c|c|c|c|c|c|}
\hline$\underline{\text { Sex }}$ & $\mathrm{n}$ & $\begin{array}{c}\text { Carapace } \\
\text { length }(\mathrm{mm})\end{array}$ & $\begin{array}{c}\text { Plastron } \\
\text { length }(\mathrm{mm})\end{array}$ & $\begin{array}{c}\text { Mass } \\
(\mathrm{g}) \\
\end{array}$ & $\begin{array}{l}\text { Age estimate } \\
\text { (annuli count) }\end{array}$ \\
\hline Male & 55 & $214.51 \pm 4.21 *$ & $191.54 \pm 11.40$ & $1173 \pm 252 * *$ & $19.7 \pm 4.2$ \\
\hline Female $^{a}$ & 83 & $201.07 \pm 10.88$ & $192.69 \pm 10.33$ & $1083 \pm 168$ & $20.4 \pm 4.1$ \\
\hline Immature & 50 & $129.56 \pm 39.73$ & $122.27 \pm 38.74$ & $375 \pm 188$ & $7.7 \pm 3.9$ \\
\hline
\end{tabular}

Note: Values are given as mean \pm standard deviation.

a all females measured during the study were included

* Significant differences between sexes, $\mathrm{t}=1.936$, df $=136, \mathrm{P}<0.05$.

** Significant differences between sexes $, \mathrm{t}=2.49, \mathrm{df}=136, \mathrm{P}<0.01$. 


\section{Discussion}

\section{Population Structure}

Our estimate of 238 turtles indicates that Wood Turtles are capable of sustaining a relatively large population at the northern limit of their range. This is the largest known population in the province of Québec. Recruitment appears to be stable, with immature turtles comprising $31 \%$ of all turtles captured. Other studies in northern areas have found immature/juvenile turtles to make up much less of the population: $8.5 \%$ in Wisconsin (Ross et al. 1991), 12\% in the Algonquin Park region, Ontario (Brooks et al. 1992), and 18.8\% for the Maitland River in Ontario (Foscarini 1994*). Populations further south seem to have more immature/juvenile turtles: 44\% in New Hampshire (Tuttle and Carroll 1997), 46\% in West Virginia (Niederberger and Seidel 1999) and 66\% in a New Jersey population (Farrell and Graham 1991). The latter study utilized captive turtles to assess reproductive characteristics and it is unclear whether captive hatched individuals were included in the analysis. Spring and fall surveys of our population showed significantly different ratios of adult to immature turtles, with a greater proportion of immature turtles being captured in the fall. This could indicate that there are seasonal differences in behaviour, activities, or habitat use between adult and immature turtles, which may be influencing the proportions captured. Further research into seasonal activity patterns and habitat use are needed for freshwater turtles, the results of which may invalidate attempts to calculate population estimates without taking behaviour into account.

Analysis of recapture data found that juvenile turtles were recaptured at a lower rate than were adult turtles. This would indicate that juvenile turtles comprise even more of the population. However, this result breaks the first assumption of mark-recapture estimates, specifically, that all individuals, including those previously marked have an equal probability of being recaptured. This assumption is rarely if ever met during studies of wild populations of animals (Leslie et al. 1955; Gibbons 1968; Begon 1979; Burnham and Overton 1979). We were able to census a large proportion of the population with relative ease and success and therefore utilized the Lincoln-Peterson method here to get a general estimate of population size (Gibbons 1968; Krebs 1989).

Due to a short growing season, where growth is not interrupted, it was assumed that not more than one growth annulus was deposited per year. Therefore, annuli act as reliable indicators of age, at least until maturity, when growth slows considerably and growth annuli are sometimes too small to distinguish (Harding and Bloomer 1979; Harding 1985*; Lovich et al. 1990). A recent study of Wood Turtles from a population in southern Québec confirmed, based on multiple recaptures, that only one annulus per year is produced (Saumure $1997^{*}$ ). However, we believe that annuli counts are at best minimums because annuli were often too small and/or too worn to count. The validity of using scute annuli to determine age has been questioned for all turtles (Cox et al. 1991; Kennett 1996; Brooks et al. 1997). However, it seems with few exceptions that in temperate climates the counting of scute annuli is a reliable estimator of an individual's age at least to or near the age of maturity (Germano and Bury 1998). Wild Wood Turtles have been known to live as long as 46 years (Ernst 2001b) and captives up to 58 years (Oliver 1955).

In the last ten years, a sufficient number of studies have been published to allow comparisons among populations. Brooks et al. (1992) proposed that average carapace length (CL) from northern Wood Turtle populations are larger and that they mature later and at a larger size than do southern populations. A more recent study (Daigle 1997) confirmed that there was a strong negative correlation between number of FFD and mean size at maturity. However, different researchers take CL measurements with slight variation in the method, some measuring a straight line between the nuchal and supracaudal notches, while others are presenting maximum CL. The differences between methods are minimal and fall well within the standard deviations, thereby allowing valid comparisons of Wood Turtle populations (Table 2). The mean CL for males and females compared (separately) to the number of frost free days (FFD) produces a strong negative correlation (males $r=0.845, \mathrm{P}<0.001$; females $r=0.829, \mathrm{P}<0.001$ ). The differences between methods in measuring CL may slightly weaken this correlation but the trend would remain. Thus, we conclude that Wood Turtles are larger (CL) as FFD decrease across the species' geographic range.

To test whether turtles were maturing later and at a larger size in northern populations, the number of FFD was compared to minimum CL at maturity and the minimum age at maturity, for males and females separately (Table 2). There was a significant correlation between minimum CL at maturity and FFD (males $r=0.734, \mathrm{P}<0.05$; females $r=0.669, \mathrm{P}<0.05)$. This suggests that Wood Turtles are maturing at a larger size in populations with fewer FFDs. There were no significant correlations between FFD and minimum age at maturity. The lack of correlation between these variables could be due to differences in assigning males and females to categories of adult, mature, or sexually mature. The variables that were constant among studies, minimum CL at first nesting (female), and secondary sexual characteristics (male), did show a correlation with FFD. Without standardization of what Wood Turtle traits should be used to assign individuals to specific categories, any relationships among these features will remain unclear.

There appears to be a general trend that male secondary sexual characteristics are apparent at fewer annuli than sexual maturity for females (Table 2). In 
TABLE 2. Comparisons of frost-free days with carapace length, age, minimum age, and size at maturity of adult Wood Turtles among 11 locations.

\begin{tabular}{|c|c|c|c|c|c|c|c|c|c|c|}
\hline \multirow[b]{2}{*}{ Location } & \multirow[b]{2}{*}{$\mathrm{FFD}^{\mathrm{a}}$} & \multicolumn{4}{|c|}{ MALES } & \multicolumn{4}{|c|}{ FEMALES } & \multirow[b]{2}{*}{ Source } \\
\hline & & $\mathrm{n}$ & $\begin{array}{c}\text { Carapace } \\
\text { length } \\
\text { Mean } \\
\text { (range) }\end{array}$ & $\begin{array}{r}\text { Numb } \\
\text { ann } \\
\text { Mean }\end{array}$ & $\begin{array}{l}\text { ser of } \\
\text { uli } \\
\text { Min. }\end{array}$ & $\mathrm{n}$ & $\begin{array}{c}\text { Carapace } \\
\text { length } \\
\text { Mean } \\
\text { (range) }\end{array}$ & $\begin{array}{r}\text { Numb } \\
\text { ann } \\
\text { Mean }\end{array}$ & $\begin{array}{l}\text { er of } \\
\text { dli } \\
\text { Min. }\end{array}$ & \\
\hline $\mathrm{ON}\left(45^{\circ} \mathrm{N}\right)$ & 90 & 21 & $\begin{array}{c}219 \\
(199-244)\end{array}$ & 21.6 & 17 & 57 & $\begin{array}{c}202 \\
(185-225)\end{array}$ & 24.6 & 18 & Brooks et al. 1992 \\
\hline $\mathrm{QC}\left(46^{\circ} \mathrm{N}\right)$ & 100 & 55 & $\begin{array}{c}215 \\
(170-242)\end{array}$ & 19.7 & 11 & 83 & $\begin{array}{c}201 \\
(181-225)\end{array}$ & 20.4 & 14 & Present study \\
\hline $\mathrm{QC}\left(45.5^{\circ} \mathrm{N}\right)$ & 113 & 9 & $\begin{array}{c}216 \\
(176-238)\end{array}$ & 16.8 & 10 & 10 & $\begin{array}{c}201 \\
(195-?)\end{array}$ & 16.8 & 15 & $\begin{array}{l}\text { Saumure and Bider } \\
\text { 1998; Saumure } 1992\end{array}$ \\
\hline $\mathrm{QC}\left(45^{\circ} \mathrm{N}\right)$ & 120 & 19 & $\begin{array}{c}195 \\
(176-211)\end{array}$ & - & - & 23 & $\begin{array}{c}182 \\
(167-209)\end{array}$ & - & - & Daigle 1997 \\
\hline WS $\left(44^{\circ} \mathrm{N}\right)$ & 140 & 28 & $\begin{array}{l}201 \\
(-)\end{array}$ & - & - & 48 & $\begin{array}{l}187 \\
(-)\end{array}$ & - & - & Ross et al. 1991 \\
\hline $\mathrm{MI}\left(46^{\circ} \mathrm{N}\right)$ & 140 & 86 & $\begin{array}{c}200 \\
(169-228)\end{array}$ & 21.5 & 12 & 10 & $\begin{array}{c}182 \\
(158-218)\end{array}$ & 20.2 & 15 & $\begin{array}{l}\text { Harding and } \\
\text { Bloomer } 1979\end{array}$ \\
\hline ON $\left(43^{\circ} \mathrm{N}\right)$ & 150 & 83 & $\begin{array}{c}198 \\
(173-?)\end{array}$ & 21.1 & 12 & 13 & $\begin{array}{c}181 \\
(158-?)\end{array}$ & 20.5 & 10 & Foscarini 1994* \\
\hline $\mathrm{NH}\left(43^{\circ} \mathrm{N}\right)$ & 150 & 17 & $\begin{array}{l}182 \\
(-)\end{array}$ & - & - & 29 & $\begin{array}{l}172 \\
(-)\end{array}$ & - & - & $\begin{array}{l}\text { Tuttle and Carroll } \\
1997\end{array}$ \\
\hline VA $\left(39^{\circ} \mathrm{N}\right)$ & 190 & 11 & $\begin{array}{l}196 \\
(-)\end{array}$ & - & 5 & 14 & $\begin{array}{l}183 \\
(-)\end{array}$ & - & - & Lovich et al. 1990 \\
\hline $\mathrm{NJ}\left(41^{\circ} \mathrm{N}\right)$ & 210 & 311 & $\begin{array}{c}178 \\
(160-206)\end{array}$ & - & $7-8$ & 464 & $\begin{array}{c}165 \\
(160-188)\end{array}$ & - & $7-8$ & $\begin{array}{l}\text { Harding and } \\
\text { Bloomer } 1979\end{array}$ \\
\hline $\mathrm{NJ}\left(41^{\circ} \mathrm{N}\right)$ & 210 & 69 & $\begin{array}{c}177 \\
(161-201)\end{array}$ & - & 14 & 49 & $\begin{array}{c}171 \\
(158-200)\end{array}$ & - & 14 & $\begin{array}{l}\text { Farrell and Graham } \\
1991\end{array}$ \\
\hline
\end{tabular}

ON-Ontario, QC-Quebec, WS-Wisconsin, MI-Michigan, NH-New Hampshire, VA-Virginia, NJ-New Jersey

Note: Approximate latitudes are estimated from locations provided in the sources.

${ }^{a}$ Mean number frost-free days (U.S. Department of Commerce, Environmental Data Service (1968) and Wilson (1971)).

this study we found males to have secondary sexual characteristics at 11 annuli, while females weren't assigned a sex until 14 annuli. This may be attributed to the fact that the only way to confirm a turtle is female is to observe her to be gravid or nesting, whereas a male can be distinguished by secondary sexual characteristics. It is possible that these characteristics begin to be displayed prior to sexual maturity thus biasing samples by inclusion of immature males. In our study, the youngest male observed attempting to copulate was 15 , while the youngest showing secondary sexual characteristics was 11 and the youngest female observed nesting was 14 . Because most mating occurs in the fall (after the year's growth) and nesting occurs in the spring (before the year's growth) it is apparent that both females and males in our northern population are sexually mature at a minimum of 15 years. Differences reported in other studies may result from comparing puberty for males with sexual maturity for females.

Differing growth rates among individuals complicate the use of a minimum age at which sexual status is assigned, because all turtles are not necessarily sexually mature at the same age. The range of CL for all turtles with 15 annuli was $170-242 \mathrm{~mm}$, a difference of $72 \mathrm{~mm}$. The small turtle $(C L=170 \mathrm{~mm})$ was recorded as immature and the large turtle $(\mathrm{CL}=242$ $\mathrm{mm}$ ) was distinctly male (Figure 1). Due to the large differences in size at a given age, we used a minimum size based on CL to assign sexual status. For many species of turtles, it has been found that size, not age, influences attainment of maturity (Cagle 1948; Gibbons 1968; Congdon et al. 1983; Ross 1989) and for other species it is age (Tinkle 1961; Graham and Doyle 1977). Table 2 illustrates that while the minimum age at which maturity was assigned 
varied greatly among populations, the general size (CL) at sexual maturity appears to be similar for most studies, approximately 160 to $180 \mathrm{~mm}$. There is, however, a correlation towards a larger minimum size at maturity at more northerly locations. A larger body size may be necessary at northern locations for sufficient reserves to be accumulated so an individual can survive hibernation and reproduce without threatening their well-being (Galbraith et al. 1989; Miller and Hickling 1990; Brooks et al. 1992; Saumure and Bider 1998).

\section{Sex and immature : adult ratios}

Sex ratios for other Wood Turtle populations have ranged from $1: 1.9$ to $1: 0.8$, males to females respectively (Farrell and Graham 1991; Ross et al. 1991). Because Wood Turtles do not show temperature dependent sex determination (Bull et al. 1985), no sexual biases are expected. Our study found that the sex ratio did not differ significantly from $1: 1$, which is similar to most other studies (Harding and Bloomer (Michigan) 1979; Harding 1985*; Farrell and Graham 1991; Ross et al. (BR site) 1991; Kaufmann 1992; Daigle 1997; Tuttle and Carroll 1997; Saumure 1997*). The few studies that show ratios significantly different from 1 : 1 (Harding and Bloomer (New Jersey) 1979; Ross et al. (WR) 1991; Foscarini 1994*) may result from either biased sampling (as was observed in our study when several females were captured at a communal nesting area, the removal of which gave a $1: 1$ ratio), factors that may be unequally removing one sex from the population (e.g., females being killed on roads while searching for a nest site), the use of inappropriate size/ age classes to distinguish males from females (as immature turtles often resemble females), or a combination of the above (Ream and Ream 1966; Gibbons 1970; Stickel 1978; Harding and Bloomer 1979; Litzgus and Brooks 1996*).

\section{Dietary Habits}

Observations of feeding habits support the claim that Wood Turtles are opportunistic omnivores (Harding and Bloomer 1979). Three feeding observations were of particular interest. A turtle cut down large fern fronds by biting through the stem and then ate only the fresh growing tips. This illustrates a complex feeding strategy that must be learned and remembered, only being applicable during a short period of the year and may indicate a degree of intelligence, previously noted for this species (Tinkelplaugh 1932). Wood Turtles may also be opportunistically carnivorous. Surface (1908) examined stomach contents of Wood Turtles and found bird remains in $8 \%$ of samples and Harding and Bloomer (1979) document the eating of eggs or young birds. Observations in our study also indicated the consumption of bird parts, either captured alive or scavenged as carrion; a similar observation was made by Niederberger and Seidel (1999). We observed turtles eating fish, bird, toad and mouse carrion. Feeding on carrion of fish and birds has also been documented by Surface (1908), Harding and Bloomer (1979), and Farrell and Graham (1991). Harding and Bloomer (1979) also document the eating of newborn mice. In captivity, Wood Turtles eat many meaty items (Harding and Bloomer 1979; Merrit 1980). Some populations have been reported to have developed an apparently successful strategy to obtain animal protein, known as "stomping", used to lure earthworms to the surface (Kaufmann 1986; Kaufmann et al. 1989). Wood Turtles did consume earthworms during the present study but this feeding strategy was not observed.

Because Wood Turtles at the northern limit of their range are larger than those from the south and their annual period of activity is shorter, northern turtles may need to consume more protein. During our study, up to four turtles were observed fighting over a piece of carrion, suggesting that meat is a favoured food. It has been suggested that growth in some turtles is limited by the relative amount of protein in their diet (Gibbons 1967; Zug 1993) and that larger body sizes can result from increased carnivory (MacCulloch and Secoy 1983).

\section{Mating}

Most of our observations of courting behaviour were in spring and fall when turtles were congregated in aquatic habitats, confirming the bimodal pattern observed by others (Carroll and Ehrenfeld 1978; Harding and Bloomer 1979; Farrell and Graham 1991; Kaufmann 1992; Foscarini 1994*). Although mating activities can occur during any month that turtles are active, it is more frequently observed in spring and fall. This may be the result of hormonal fluctuations (Licht 1982) and/or simply because males and females are congregated in aquatic habitats during these periods (Harding and Bloomer 1979). In an Ontario population, $50 \%$ of courting behaviour observed was during May and there was at least one observation per month from June to September, but very little observation was conducted during September and October (Foscarini 1994*). The frequency of fall mating may have been overlooked in that study (telemetry surveys were conducted every three to four weeks) (Foscarini 1994*). In our study, $50 \%$ of the courting activities were observed during October alone, and $70 \%$ occurred during the fall. If anything, this was an underestimate of the importance of the fall mating period, as we also spent less time in the field during the autumn months. Similar results showing an increase in mating behaviour in the fall were reported by Harding (1990). Carroll and Ehrenfeld (1978) observed that mating behaviours peaked in the spring, with a second mating period occurring in September and October. They also reported that fall mating attempts were longer than those in the spring. Further support of the importance of the fall mating period is provided by Kaufmann (1992), who also found that fall mountings were of a longer duration than spring mountings and that significantly 
more fall mating attempts resulted in insemination. The suggestion that the increase in mating behaviour in fall was a result of hormonal fluctuations was confirmed by Licht (1982) who reported that testosterone production and spermatogenesis peak during late summer and fall. In Nova Scotia, Powell (1967) found that female turtles in summer and fall have mature follicles, which are then stored over winter, and ovulated in the spring. If the fall is, in fact, the primary mating period for this species, females must be capable of storing sperm to fertilize eggs the following spring, as has been suggested by another study (Kaufmann 1992). The storage of viable sperm for over one year has been documented for many other species of North American turtles (Smith 1956; Berry and Shine 1980; Gist and Jones 1989), but has not been shown for Wood Turtles. While we have no evidence that our population has longer mating attempts in the fall or that there is a greater frequency of sperm transfer during this period, the fact that $70 \%$ of mating attempts observed occurred in the fall may indicate that the fall mating period is more important. At our northern location there is little post-hibernation time (2-3 weeks) in the spring before it is necessary for female turtles to ovulate their mature follicles, in preparation for oviposition by mid-June. If the spring was the period that was important for mating activities, we should have observed numerous matings in the spring, but did not. Disturbances to Wood Turtle populations during the fall may disrupt mating activities and have a negative effect on reproductive output.

Our observations that mating occurred most often between 11:00 and 13:00 differ from those reported in other studies. Farrell and Graham (1991) report that mating was commonly observed in the early morning, while others (Harding and Bloomer 1979) report that it is most often observed in late afternoon. It is possible that our population was mating during the midday period because this is the time at which the turtle has had sufficient time to emerge from the water and bask to increase its body temperature. Turtles are typically temperature sensitive related to their activity and turtles that are larger, as our study population was, may require more basking time to reach temperatures that are ideal for normal activity (Boyer 1965; CloudseyThompson 1971; Hutchison 1979; Huey 1982). In a controlled experiment, Wood Turtles maintained at a higher temperature had several activity periods during the day, while those kept at a lower temperature had only one activity period centered around midday (Graham and Dadah-Tosti 1981). Our observations of mating behaviour centered around midday may be explained by these results. This could also explain why mating behaviour in southern populations occurs during the early morning and evening, times at which turtles were more active (Harding and Bloomer 1979; Farrell and Graham 1991).

\section{Injuries, Predation, and Parasites}

Commonly reported injuries to Wood Turtles include tail loss, partial or complete amputation of limb(s) and shell damage (Farrell and Graham 1991; Brooks et al. 1992; Kaufmann 1992; Foscarini 1994*; Gilhen et al. 1994*; Saumure and Bider 1998) all of which may eventually lead to premature death. Partial tail loss was the most common reported injury and the rate of loss, $24.5 \%$ in our study, is within the range of other studies, 59\% in Ontario (Foscarini 1994*) to $16.8 \%$ in New Jersey (Farrell and Graham 1991). As in Saumure and Bider (1998), there was no difference for the rates of partial tail amputation between sexes in adults; however, loss was less in immature turtles. This may simply be an artifact of adult turtles having lived longer. It is also possible that immature turtles, because their shell is not completely ossified (Zug 1991) are more often killed outright (Wilbur 1975; Bury 1979). However, tail damage may not be solely the result of predation but may also be inflicted during aggressive adult turtle encounters for dominance and mate selection. Tail injuries are known to be caused by conspecifics in captivity (Bell 1972). During this study, aggressive encounters in which tail biting occurred were observed between males and males, females and males (precopulatory), and females and females. Prolonged tail biting by turtles of the genera Clemmys and Glyptemys is known to occur during agonistic encounters is considered to be a highly aggressive act (Ernst 1967; Kaufmann 1992), but it is not clear if any permanent damage is incurred. During this study, bleeding was observed on two occasions after a tail had been bitten, once in a male-male encounter and the other in a female-female. ADW, having being bitten on a finger by a female Wood Turtle has experienced the strength of a Wood Turtle's bite, which removed a large chunk of skin and left a deep wound. It is possible that such an attack to a tail could sever the caudal veins, causing part of the tail to atrophy.

The results obtained for limb amputation (9.6\%) are similar to those obtained by others: $9.6 \%$, Harding and Bloomer (1979); 8.6\%, Farrell and Graham (1991); $12.9 \%$, Foscarini $(1994 *)$. The percentage having two limbs partially amputated $(3.2 \%)$ is similar to that reported by Harding and Bloomer (1979). Several studies report that it is not uncommon to find turtles with one or two limbs chewed off by a predator such as a raccoon (Harding and Bloomer 1979; Harding 1985; Farrell and Graham 1991) or otter (Gilhen et al. $\left.1994^{*}\right)$, but in the latter study it is not clear whether they observed this mutilation directly. A study in southern Québec (Saumure and Bider 1998) reported a much higher rate of limb amputation, $32.3 \%$, and a double amputation rate of $13 \%$. Saumure and Bider (1998) suggested that a few very efficient predators or the relative abundance/density of the predatory species could explain the high rates of limb amputation. The 
effects of limb amputations on turtles are unknown. However, Harding (1985) did notice there were significantly fewer injured turtles recaptured during his study, suggesting that long-term survival may be compromised.

The seasonal occurrence of leeches on Wood Turtles has been well documented (Koffler et al. 1978; Harding and Bloomer 1979; Farrell and Graham 1991; Foscarini 1994*; Saumure and Bider 1996). We found no turtles with leeches during summer months and believe that this is because Wood Turtles are primarily terrestrial at this time, as has been suggested by others. While some studies report leeches on Wood Turtles in all months (Harding and Bloomer (Michigan) 1979; Foscarini $1994 *$ ), each presence is highest in the spring. These latter observations are from populations in the western part of the species' range; these populations are thought to be more aquatic than eastern populations (Harding and Bloomer 1979).

\section{Population Density}

The density of Wood Turtles in our study area was approximately 0.44 turtles per hectare (tu/ha). This density is slightly higher than that for turtles from a population in central Ontario, 0.24 tu/ha (Brooks et al. 1992), a site where the number of frost-free days (FFD) is lower than ours (Table 3). Densities of Wood Turtles from southern locations with more FFD are greater, for example, $2.6 \mathrm{tu} / \mathrm{ha}$ for a New Hampshire population (Tuttle and Carroll 1997) and 10.7 tu/ha for a population in New Jersey (Farrell and Graham 1991). The density of turtles is strongly positively correlated with the number of FFD $(r=0.947, \mathrm{P}<0.01)$. It is possible that because northern turtles are larger they require a greater area in which to forage to obtain the necessary resources and build sufficient fat reserves to survive the longer winters. Arvisais et al. (2002) noted that there was a trend towards larger home ranges in northern populations. It could also be that the general trend of decreasing biodiversity and primary productivity associated with shorter growing seasons may be limiting the numbers and/or the variety of food available to northern turtles (Fleming 1973; Heywood 1978; Currie and Paquin 1987; Cox and Moore 1995). This could be forcing turtles to utilize a larger area so dietary requirements can be met. Food availability has been suspected of limiting the density of other turtles (Ross 1989) and may help explain the aggressive encounters we observed over food.

\section{Acknowledgments}

This study was part of a larger program initiated by Société de la faune et des parcs du Québec, Direction de la faune et des habitats, Parks Canada, St. Lawrence Valley Natural History Society, McGill University, and l'Université du Québec à Trois-Rivières. Funding, equipment, and personnel for this research were generously provided to the St. Lawrence Valley Natural History Society by Parks Canada, Fondation de la Faune du Québec, and Société de la faune et des parcs du Québec. We thank all those who aided this project by assisting with the field work. Earlier drafts of the manuscript were improved by discussions with and/or reviews by Francis Cook, R. K. Stewart, Marcella Trembley, David Rodrigue, Raymond Saumure, and two anonymous reviewers. This paper was submitted in partial fulfillment of the requirements for the degree of Master of Science to the Department of Natural Resource Sciences of McGill University.

Documents Cited (marked with * after date in text)

Allard, M. 1978. Parc national de la Mauricie, étude géomormophologie. Rapport final préparé pour Parcs Canada. Laboratoire de Géomorphologie, Départment de géographie, Université Laval, Québec. 155 pages.

Foscarini, D. A. 1994. Demography of the Wood Turtle (Clemmys insculpta) and habitat selection in the Maitland River Valley. M.Sc. thesis, University of Guelph, Ontario. 108 pages.

Gilhen, J., T. Herman, and N. Meister. 1994. The Wood Turtle: an uncertain future in Nova Scotia. Turtle Watch, Centre for Wildlife and Conservation Biology. Acadia University, Nova Scotia. Unpublished. 5 pages.

Harding, J. H. 1985. Comments on age determination and growth in the Michigan population of the Wood Turtle (Clemmys insculpta). Combined meeting of SSAR and HL. University of South Florida, Tampa. Page 149. (Abstract)

Harding, J. H. 1991. Communications. Clemmys Interest Group Newsletter (May). 4 pages.

TABLE 3. Comparison of frost-free days and Wood Turtle density (number of turtles/hectare) among six locations.

\begin{tabular}{lccc}
\hline \hline & FFD $^{\mathbf{a}}$ & turtles/hectare & Source \\
\hline \hline Ontario $\left(45^{\circ} \mathrm{N}\right)$ & 90 & 0.24 & Brooks et al. 1992 \\
Québec $\left(46^{\circ} \mathrm{N}\right)$ & 100 & 0.44 & Present study \\
Michigan $\left(46^{\circ} \mathrm{N}\right)$ & 140 & 2.5 & Harding and Bloomer 1979 \\
New Hampshire $\left(43^{\circ} \mathrm{N}\right)$ & 150 & 2.6 & Tuttle and Carroll 1997 \\
New Jersey $\left(41^{\circ} \mathrm{N}\right)$ & 210 & 10.7 & Farrell and Graham 1991 \\
New Jersey $\left(41^{\circ} \mathrm{N}\right)$ & 210 & 12.5 & Harding and Bloomer 1979 \\
\hline \hline
\end{tabular}

Note: Approximate latitudes are estimated from locations provided in the sources.

${ }^{\text {a }}$ Mean number frost-free days (U.S. Department of Commerce, Environmental Data Service (1968) and Wilson (1971)). 
Klemens, M. W. 1992. Proposal to amend C.I.T.E.S. Appendix II, with addition of: Wood Turtle Clemmys insculpta (Le Conte). Unpublished. 7 pages.

Litzgus, J. D., and R. J. Brooks. 1996. Status of the Wood Turtle, Clemmys insculpta, in Canada. COSEWIC report, draft copy 14 February, 1996. Unpublished. 70 pages.

Saumure, R. A. 1995. Turtle research in the Big Creek National Wildlife Area. Report to Canadian Wildlife Service. London, Ontario. 81 pages.

Saumure, R. A. 1997. Growth, mutilation, and age structure of two populations of Wood Turtles (Clemmys insculpta) in southern Québec. M.Sc. thesis, McGill University, Québec. Unpublished. 70 pages.

\section{Literature Cited}

Arvisais, M., J.-C. Bourgeois, E. Levesque, C. Daigle, D. Masse, and J. Jutras. 2002. Home range and movements of a Wood Turtle (Clemmys insculpta) population at the northern limit of its range. Canadian Journal of Zoology 80: 402-408

Beaulieu, H. 1992. Liste de la faune vertébrée susceptible d'être désignée menacée ou vulnérable. Québec, Ministère du Loisir, de la Chasse et de la Pêche.

Begon, M. 1979. Investigating animal abundance: capturerecapture for biologists. Edward Arnold Limited, London.

Bell, V. 1972. Turtle of the month. New York Turtle and Tortoise Society 1: 5-7.

Berry, J. F., and R. Shine. 1980. Sexual size dimorphism and sexual selection in turtles (order Testudines). Oecologia 44: 185-191.

Bider, J. R., and S. Matte. 1996. An atlas of reptiles and amphibians of Québec. St. Lawrence Valley Natural History Society and Ministère de l'Environnement et de la Faune, Québec.

Boyer, D. R. 1965. Ecology of the basking habit in turtles. Ecology 46: 99-118.

Brewster, K. N., and C. M. Brewster. 1991. Movement and microhabitat use by juvenile Wood Turtles introduced into a riparian habitat. Journal of Herpetology 25: 379382.

Brooks, R. J., C. M. Shilton, G. P. Brown, and N. W. S. Quinn. 1992. Body size, age distribution, and reproduction in a northern population of Wood Turtles (Clemmys insculpta). Canadian Journal of Zoology 70: 462-469.

Brooks, R. J., M. A. Krawchuk, C. Stevens, and N. Koper. 1997. Testing the precision and accuracy of age estimation using lines in scutes of Chelydra serpentina and Chrysemys picta. Journal of Herpetology 31: 521-529.

Buhlmann, K. 1992. Legislation \& conservation alert. Herpetological Review 23: 66.

Buhlmann, K. A. 1993. Legislation \& conservation alert. Herpetological Review 24: 125.

Bull, J. J., J. M. Legler, and R. C. Vogt. 1985. Nontemperature dependent sex determination in two suborders of turtles. Copeia 1985: 784-786.

Burnham, K. P., and W. S. Overton. 1979. Robust estimation of population size when capture probabilities vary among animals. Ecology 60: 927-936.

Bury, R. B. 1979. Population ecology of freshwater turtles. Pages 571-602 in Turtles: Perspectives and Research. Edited by M. Harless and H. Morlock. John Wiley and Sons Publishing, New York.

Cagle, F. R. 1939. A system for marking turtles for future identification. Copeia 1939: 170-173.
Cagle, F. R. 1948. Sexual maturity in the male turtle, Pseudemys scripta troostii. Copeia 1948: 108-111.

Carroll, T. E., and D. W. Ehrenfeld. 1978. Intermediaterange homing in the Wood Turtle. Copeia 1978: 117-126.

Cloudsey-Thompson, J. L. 1971. The temperature and water relation in reptiles. Merrow Publication Co. Ltd. Watford Herts, England.

Congdon, J. D., D. W. Tinkle, G. L. Breitenbach, and R. van Loben Sels. 1983. Nesting ecology and hatching success in the turtle Emydoidea blandingi. Herpetologica 39: 417-429.

Cox, C. B., and P. D. Moore. 1995. Biogeography: An ecological and evolutionary approach. Blackwell Science Ltd. Cambridge, Massachusetts.

Cox, W. A., J. B. Hazelrig, M. E. Turner, R. A. Angus, and K. R. Marion. 1991. A model for growth in the Musk Turtle, Sternotherus minor, in a north Florida spring. Copeia 1991: 954-968.

Currie, D. J., and V. Paquin. 1987. Large-scale biogeographical patterns of species richness of trees. Nature 329 : 326-327.

Daigle, C. 1997. Size and characteristics of a Wood Turtle, Clemmys insculpta, population in southern Québec. Canadian Field-Naturalist 111: 440-444.

Ernst, C. H. 1967. A mating aggregation of the turtle Clemmys guttata. Copeia 1967: 473-474.

Ernst, C. H. 1986. Environmental temperatures and activities in the Wood Turtle, Clemmys insculpta. Journal of Herpetology 20: 222-229.

Ernst, C. H. 2001a. An overview of the North American turtle genus Clemmys Ritgen, 1828. Chelonian Conservation and Biology 4: 211-216.

Ernst, C. H. 2001b. Some ecological parameters of the Wood Turtle, Clemmys insculpta, in southeastern Pennsylvania. Chelonian Conservation and Biology 4: 94-99.

Ernst, C. H., J. E. Lovich, and R. W. Barbour. 1994. Turtles of the United States and Canada. Smithsonian Institution Press, Washington.

Farrar, J. L. 1995. Trees in Canada. Fitzhenry and Whiteside Limited, Ontario.

Farrell, R. F., and T. E. Graham. 1991. Ecological notes on the turtle Clemmys insculpta in Northwestern New Jersey. Journal of Herpetology 25: 1-9.

Fleming, T. H. 1973. Numbers of mammal species in North and Central American forest communities. Ecology 54: 555-563.

Froese, A. D., and G. M. Burghardt. 1975. A dense natural population of the common Snapping Turtle (Chelydra s. serpentina). Herpetologica 31: 204-208.

Galbraith, D. A., R. J. Brooks, and M. E. Obbard. 1989. The influence of growth rate on age and body size at maturity in female Snapping Turtles (Chelydra serpentina). Copeia 1989: 896-904.

Galois, P., and J. Bonin. 1999. Rapport sur la situation de la Tortue des Bois (Clemmys insculpta) au Québec. Faune et Parcs Québec, Direction de la faune et des habitats, Québec.

Garber, S. D. 1989. Population ecology of the Wood Turtle (Clemmys insculpta). Pages 31-35 in Proceedings, 12th International Herpetological Symposium. Edited by M. J. Rosenberg. Thurmont, Maryland.

Garber, S. D., and J. Burger. 1995. A 20-yr study documenting the relationship between turtle decline and human recreation. Ecological Applications 5: 1151-1162. 
Germano, D. J., and R. B. Bury. 1998. Age determination in turtles: Evidence of annual deposition of scute rings. Chelonian Conservation and Biology 3: 123-132.

Gibbons, J. W. 1967. Variation in growth rates in three populations of the Painted Turtle, Chrysemys picta. Herpetologica 23: 296-303.

Gibbons, J. W. 1968. Population structure and survivorship in the Painted Turtle (Chrysemys picta). Copeia 1968: 260268.

Gibbons, J. W. 1970. Sex ratios in turtles. Researches on Population Ecology 12: 252-254.

Gist, D. H., and J. M. Jones. 1989. Sperm storage within the oviduct of turtles. Journal of Morphology 199: 379384.

Graham, T. E., and S. D. Doyle. 1977. Growth and population characteristics of Blanding's Turtle, Emydoidea blandingii, in Massachusetts. Herpetologica 33: 410-414.

Graham, T. E., and J. Dadah-Tosti. 1981. Temperature effects on locomotor patterns in the Wood Turtle, Clemmys insculpta. Bulletin of the Maryland Herpetological Society 17: 74-77.

Green, D. M. 1996. COSEWIC designates the Wood Turtle a vulnerable species. Canadian Association of Herpetologists, Bulletin. 10: 9.

Harding, J. H. 1985. Clemmys insculpta. Predation-mutilation. Herpetological Review 16: 30.

Harding, J. H. 1990. A twenty year Wood Turtle study in Michigan: implication for conservation. Pages 31-35 in Proceedings of the First International Symposium on turtles and tortoises: conservation and captive husbandry. Edited by K. R. Beamen, R. Kent, F. Caporaso, S. McKeown, and M. D. Graff. California Turtle and Tortoise Club.

Harding, J. H., and T. J. Bloomer. 1979. The Wood Turtle, Clemmys insculpta ... a natural history. (Herp) Bulletin of the New York Herpetological Society 15: 9-26.

Heywood, V. H. Editor. 1978. Flowering plants of the world. Oxford University Press, Oxford.

Huey, R. B. 1982. Temperature, physiology and the ecology of reptiles. Pages 25-91 in Biology of the Reptilia, Volume 12 Physiology (C): Physiological Ecology. Edited by C. Gans and F. H. Pough. Academic Press, London, England.

Hutchison, V. H. 1979. Thermoregulation. Pages 207-228 in Turtles: Perpectives and Research. Edited by M. Harless and H. Morlock. J. Wiley and Sons, New York.

Kaufmann, J. H. 1986. Stomping for earthworms by Wood Turtles, Clemmys insculpta: a newly discovered foraging technique. Copeia 1986: 1001-1004.

Kaufmann, J. H. 1992. The social behaviour of Wood Turtles (Clemmys insculpta) in Central Pennsylvania. Herpetological Monographs 6: 1-25.

Kaufmann, J. H. 1995. Home ranges and movements of Wood Turtles, Clemmys insculpta, in central Pennsylvania. Copeia 1995: 22-27.

Kaufmann, J. H., J. H. Harding, and K. N. Brewster. 1989. Worm stomping by Wood Turtles revisited. Bulletin of the Chicago Herpetological Society 24: 125-126.

Kennett, R. 1996. Growth models for two species of freshwater turtle, Chelodina rugosa and Elseya dentata, from the wet-dry tropics of northern Australia. Herpetologica 52: 383-395.

Koffler, B. R., R. A. Seigel, and M. T. Mendonca. 1978. The seasonal occurrence of leeches on the Wood Turtle, Clemmys insculpta, (Reptilia, Testudines, Emydidae). Journal of Herpetology 12: 571-572.
Krebs, C. J. 1989. Ecological methodology. Harper Collins, New York.

Leslie, P. H., D. Chitty, and H. Chitty. 1955. The estimation of population parameters from data obtained by means of capture-recapture method. III. An example of the practical applications of the method. Biometrika 40: 137-169.

Levell, J. P. 2000. Commercial exploitation of Blanding's Turtle, Emydoidea blandingii, and the Wood Turtle, Clemmys insculpta, for the live animal trade. Chelonian Conservation and Biology 3: 665-674

Lindeman, P. V. 1990. Closed and open model estimates of abundance and tests of model assumptions for two population of the turtle, Chrysemys picta. Journal of Herpetology 24: 78-81.

Licht, P. 1982. Endocrine patterns in the reproductive cycle of turtles. Herpetologica 38: 51-61.

Lovich, J. E., C. H. Ernst, and J. F. McBreen. 1990. Growth, maturity, and sexual dimorphism in the Wood Turtle, Clemmys insculpta. Canadian Journal of Zoology 68: 672-677.

MacCulloch, R. D., and D. M. Secoy. 1983. Demography, growth, and food of Western Painted Turtles, Chrysemys picta belli (Gray), from southern Saskatchewan. Canadian Journal of Zoology 61: 1499-1509.

Merrit, D. A. 1980. The Wood Turtle, Clemmys insculpta. Natural history, behaviour, and food habits. Bulletin of the Chicago Herpetological Society 15: 6-9.

Miller, J. S., and G. J. Hickling. 1990. Fasting endurance and the evolution of mammalian body size. Functional Ecology 4: 5-12.

Niederberger, A. J., and M. E. Seidel. 1999. Ecology and status of a Wood Turtle (Clemmys insculpta) population in West Virginia. Chelonian Conservation and Biology 3: 414-418.

Oliver, J. A. 1955. The natural history of North American amphibians and reptiles. Van Nostrand, Princeton.

Pollock, K. H., J. D. Nichols, C. Brownie, and J. E. Hines. 1990. Statistical inference for capture-recapture experiments. Wildlife Monographs 107: 1-97.

Powell, C. B. 1967. Female sexual cycles of Chrysemys picta and Clemmys insculpta in Nova Scotia. Canadian FieldNaturalist 81: 134-140.

Quinn, N. W. S., and D. P. Tate. 1991. Seasonal movements and habitat of Wood Turtles (Clemmys insculpta) in Algonquin Park, Canada. Journal of Herpetology 25: 217-220.

Ream, C., and R. Ream. 1966. The influence of sampling methods on the estimation of population structure in Painted Turtles. American Midland Naturalist 75: 325-338.

Ross, D. A. 1989. Population ecology of Painted and Blanding's turtles (Chrysemys picta and Emydoidea blandingi) in Central Wisconsin. Wisconsin Academy of Science, Arts, and Letters 77: 77-84.

Ross, D. A., K. N. Brewster, R. K. Anderson, N. Ratner, and C. M. Brewster. 1991. Aspects of the ecology of Wood Turtles, Clemmys insculpta, in Wisconsin. Canadian FieldNaturalist 105: 363-367.

Saumure, R. A. 1992. Clemmys insculpta (Wood Turtle). Size. Herpetological Review 23:116.

Saumure, R. A., and J. R. Bider. 1996. Clemmys insculpta (Wood Turtle). Ectoparasites. Herpetological Review 27: 197-198.

Saumure, R. A., and J. R. Bider. 1998. Impact of agricultural development on a population of Wood Turtles (Clemmys insculpta) in Southern Québec, Canada. Chelonian Conservation and Biology 3: 37-45. 
Smith, H. M. 1956. Handbook of amphibians and reptiles of Kansas. University of Kansas Museum of Natural History Miscellaneous Publications 9: 1-356.

SPSS Inc. 2002. SigmaPlot 8.02 user's guide. SPSS Inc. Chicago, Illinois.

Stickel, L. F. 1978. Changes in a Box Turtle population during three decades. Copeia 1978: 221-225.

Surface, H. A. 1908. First report on the economic features of the turtles of Pennsylvania. Zoological Bulletin, Division of Zoology, Pennsylvania Department of Agriculture 6: 105-196.

Tinkelplaugh, O. 1932. Maze learning of a turtle. Journal of Comparative Psychology 13: 201-206.

Tinkle, D. W. 1961. Geographic variation in reproduction, size, sex ratio and maturity of Sternothaerus odoratus (Testudinata: Chelydridae). Ecology 42: 68-76.

Tuttle, S. A., and D. M. Carroll. 1997. Ecology and natural history of the Wood Turtle (Clemmys insculpta) in south New Hampshire. Linnaeus Fund Research Report. Chelonian Conservation and Biology 2: 447-449.
United States Environmental Data Service. 1968. Climatic atlas of the United States. Environmental Data Service, Washington, D.C.

Wilbur, H. M. 1975. The evolutionary and mathematical demography of the turtle Chrysemys picta. Ecology 56: 64-77.

Wilson, C. V. 1971. The climate of Québec. Part One. Climatic Atlas. Canadian Meteorological Service.

Wright, A. H. 1918. Notes on Clemmys. Proceedings of the Biological Society of Washington 31: 51-58.

Zug, G. R. 1991. Age determination in turtles. Society for the Study of Amphibians and Reptiles, Herpetological Circular 20. 28 pages.

Zug, G. R. 1993. Herpetology. An introductory biology of amphibians and reptiles. Academic Press Incorporated, New York.

Received 2 April 2001

Accepted 12 November 2003 